\title{
CHEMICAL COMPOSITION AND HYDRAULIC CONNECTIVITY OF SPRINGS IN THE SOUTHERN SLOPE OF MERAPI VOLCANO
}

\author{
Johnny Boulom*1, Doni Prakasa Eka Putra ${ }^{2}$, and Wahyu Wilopo ${ }^{2}$ \\ ${ }^{1}$ Department of Civil and Environmental Engineering, National University of Laos \\ ${ }^{2} 2$ Department of Geological Engineering, Faculty of Engineering, Gadjah Mada University
}

\begin{abstract}
Springs are easily found in the southern slope of Merapi volcano, Sleman Regency, Yogyakarta Special Province, Indonesia. Springs origins on this location are commonly related to the existing of Merapi Aquifer System, but importance question of all these springs are hydraulic connectivity among them. In response to the issue, the objective of this research is to determine hydraulic connectivity of springs based on their chemical composition. To answer the objectives, measurement of spring discharge and physicochemical properties of spring's water and sampling of selected spring's water were conducted on this research in the study area. Water chemistry composition was classify by Kurlov formula and displayed by Fingerprint diagram and Composition diagram. Results show that the chemical compositions of most all spring samples are almost similar and does not significantly different for most properties from upstream to downstream, which are $\mathrm{Na}-\mathrm{Ca}-\mathrm{HCO}_{3}$ water, only one spring of Umbul Jatiningsih spring had different chemical composition of $\mathrm{Ca}-\mathrm{Na}-\mathrm{Mg}-$ $\mathrm{HCO}_{3}$ water. Based on the Fingerprint diagram and Composition diagram evaluation, the spring's water can be differentiated into three groups. Group 1 consists of ten springs which have similar chemical composition of $\mathrm{Na}-\mathrm{Ca}-\mathrm{HCO}_{3}$ and with electrical conductivity ranges between 150 to $200 \mu \mathrm{S} / \mathrm{cm}$. Group 2 consists only one spring "Umbul Pajangan" which contain similar chemical composition to
\end{abstract}

*Corresponding author: J. BOULOM, Department of Civil and Environmental Engineering, National University of Laos. E-mail: johnny_boulom@yahoo.com
Group 1 but has significantly higher ions concentration (EC value about $400 \mu \mathrm{S} / \mathrm{cm}$ ) and Group 3 consists also only one spring "Umbul Jatiningsih" which has significantly different ionic composition with Group 1 and 2. Regarding on this condition, it can be concluded that Group 1 spring is hydraulically connected and relate to the shallow aquifer system of Merapi Aquifer System. In other side, water of spring "Umbul Pajangan" possibly comes from deeper aquifer system of Merapi Aquifer System and this argument is supported by the spring discharge evaluation. Finally, spring "Umbul Jatiningsih" is originate mainly from different aquifer system of porous limestone aquifer.

Keywords: Merapi aquifer system, spring, chemical composition, geological condition

\section{Introduction}

Merapi Aquifer System is an aquifer system developed in the southern slope of Merapi Volcano which introduced firstly by MacDonald and Partners (1984). According to MacDonald and Partners (1984), the springs on MAS can be divided into two types of occurrence, northern group of springs and southern group of springs. Northern group of springs is either within incised river valleys or where bands of ash or clay provide an impermeable layer. Southern group of springs occurs approximately at the break in topographic slope between lower slope of volcano and foot of volcano morphology. All of these springs seem to be hydraulically con- 
nected according to the conceptual section of MAS by MacDonald and Partners (1984).

Determination of aquifer hydraulic connectivity can be conducted by evaluation of the isotopes and chemical composition of water (Mazor, 2004; Praamsma et al. 2008; Jai et al., 2013). Application of stable isotopes $\left(\delta^{18} \mathrm{O}\right.$ and $\left.\delta^{2} \mathrm{H}\right)$ for understanding the hydraulic connectivity of some springs and wells in the southern slope of Merapi Volcano has also reported by Wijatna et al. (2013). Based on the stable isotopes analysis, Wijatna et al. (2003) concluded that the springs located on the elevation between 600 to 1200 masl of southern slope of Merapi do not have hydraulic connection with springs located on the elevation between 300 to 500 masl of southern slope of Merapi, although the source of water for the lower elevation spring comes from higher elevation. Results from Wijatna et al. (2013) is contradictive and opposite to the statement of MacDonald and Partners (1984), therefore in response to this problem, this research paper attempt to determine the hydraulic connectivity of springs in the southern slope of Merapi based on its chemical composition and geological condition.

\section{Location and geological setting}

The study area is located in the southern slope of Merapi Volcano of Sleman regency (see Figure 11. The study area can be differentiated into three zones of morphologies; Upper slope of Merapi Volcano, Middle slope of Merapi Volcano and Lower slope of Merapi Volcano. Upper slope zone located 900 meters above sea level (masl) and has slope of more than 50\%. The middle slope zone has located between 900 masl elevation and 150 masl, it has average gradient slope less than $20 \%$. The lower slope zone is bordered with elevation of about 150 masl, this area has slope less than 5\% (MacDonald and Partners, 1984).

The geology of the study area are composed by tertiary rocks and quaternary succession of Merapi volcano (MacDonald and Partners, 1984). The tertiary rocks of old andesite formation and limestone sentolo formation occur on southwest and west of the study area (see
Figure 2). The quarternary succession can be differentiated into two groups; Old Merapi volcanic formation and Young Merapi volcanic formation. The outcrop of old volcanic merapi distribute on the upper slope of Merapi Volcano (see Figure 2). The young merapi volcanic deposits are largely attributable in the study area. This young merapi volcanic formation divided into two deposits; Sleman formation and Yogyakarta formation (MacDonald and Partners, 1984). Referring to MacDonald and Partners (1984), the Sleman Formation has been designed as the lower part of a major volcaniclastic unit which was formerly include in the Younger Merapi Volcanics. In the north, on the Merapi Upper Slopes, it consists of sands and gravels with interspersed boulders, all derived from volcanic ejector. The Yogyakarta Formation forms the surface outcrop from the Merapi Middle Slopes of the study area. It constitutes the upper part of the former Younger Merapi Volcanics. The formation consists of an interbedded sequence of sands, gravels, silts and clays.

The Sleman and Yogyakarta Formation are built the productive aquifer of Merapi Aquifer System (MacDonald and Partners, 1984). The Merapi Aquifer System or MAS conceptual model of the study area can be seen in Figure 3. On this figure, the Sleman formation becomes the lower aquifer of MAS and Yogyakarta formation develops an upper aquifer of MAS. The thickness of MAS in the study area is ranges from $20 \mathrm{~m}$ in the vicinity of north, west and east boundaries to about $100 \mathrm{~m}$ in the area near Yogyakarta City (Putra, 2003). In the study area, the groundwater flows from north to the south, with shallow depth of groundwater level. Springs are common to be found on the study area as also shown in the MAS conceptual model. Those springs are used to fulfill domestic water demand and also used for irrigation supply. The discharge of springs are vary from $1 \mathrm{~L} / \mathrm{s}$ to about $1000 \mathrm{~L} / \mathrm{s}$, in which high discharge springs are commonly found in the Sleman Formation. 


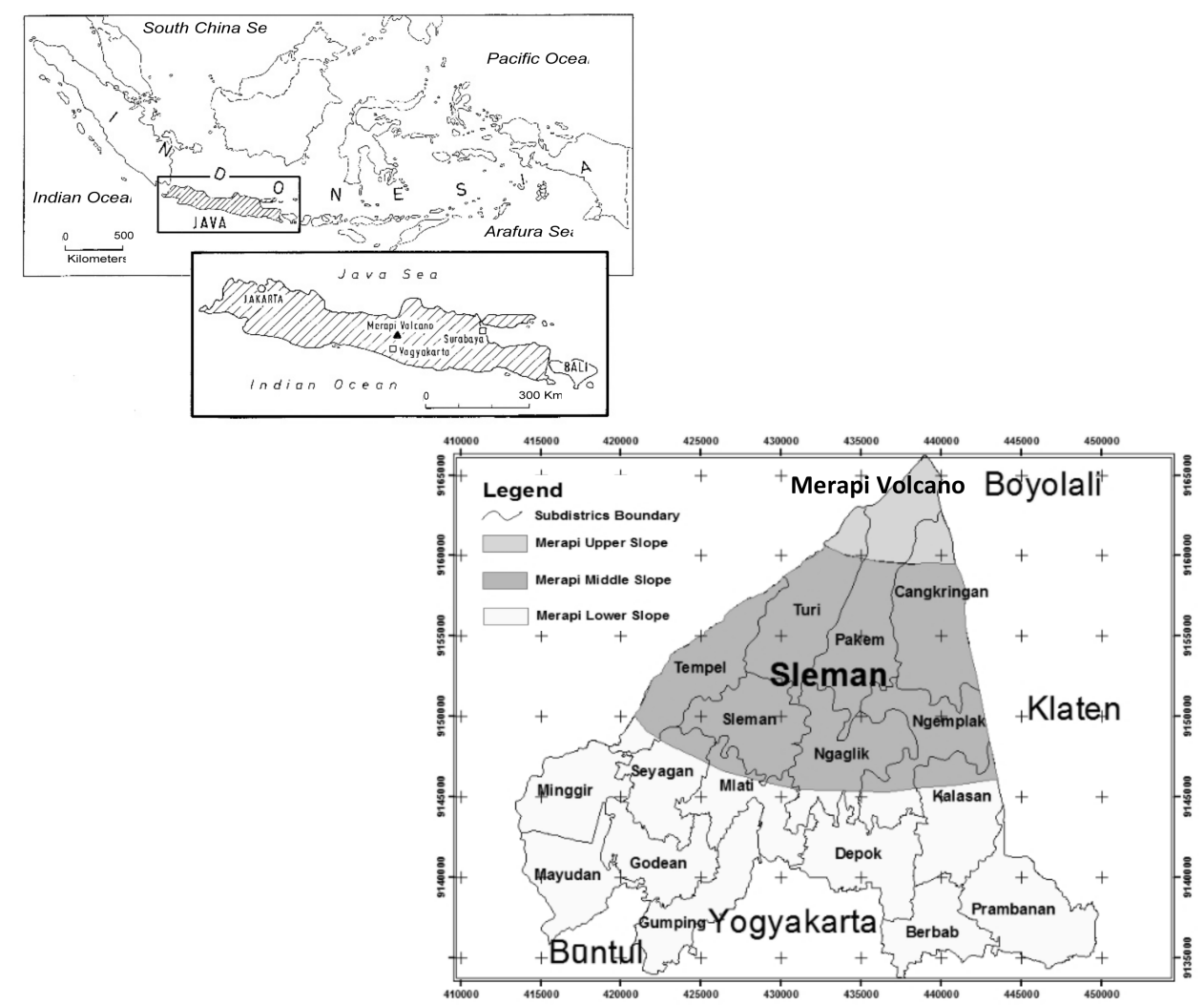

Figure 1: Location of the study area and morphology zones in the study area (modified from MacDonald and Partners, 1984).

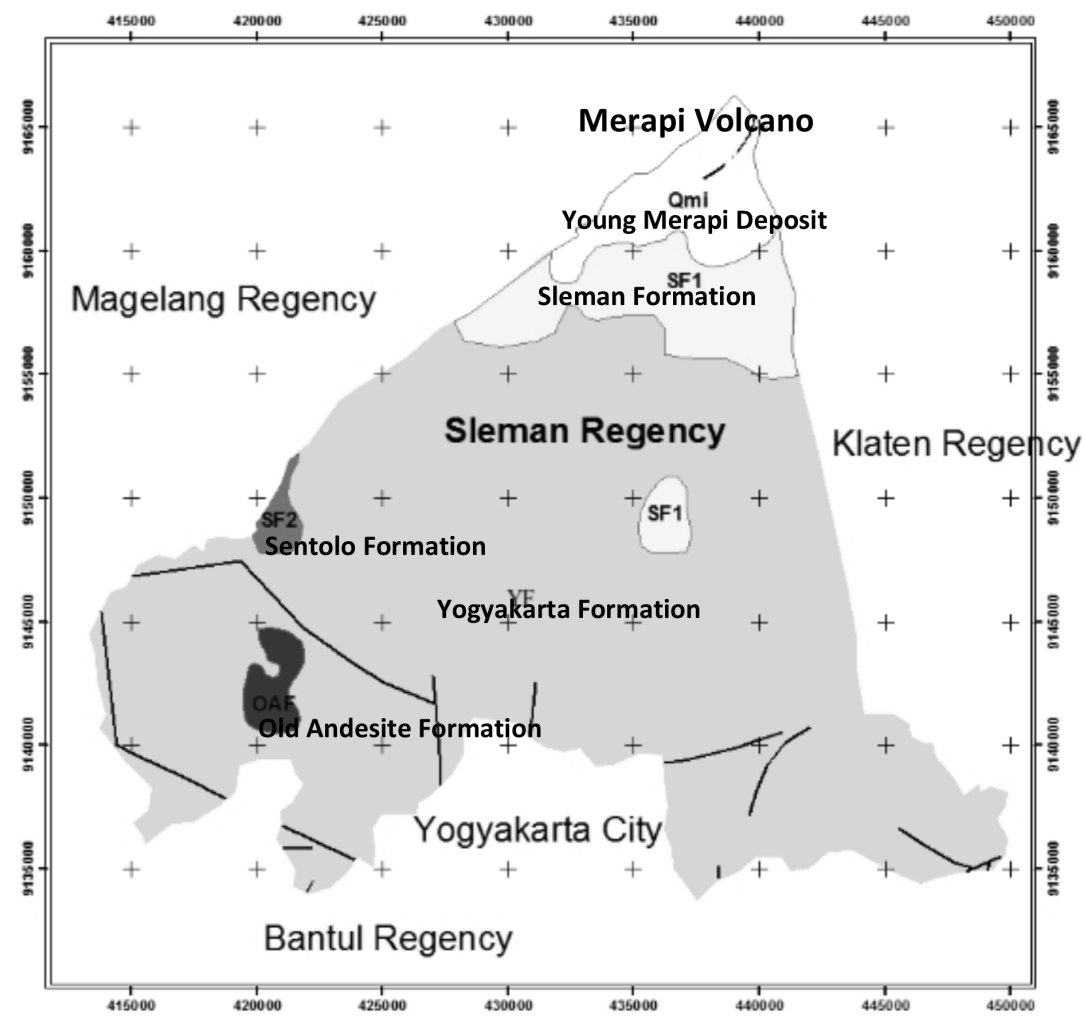

Figure 2: The geology of the study area (Modified from MacDonald and Partners, 1984). 


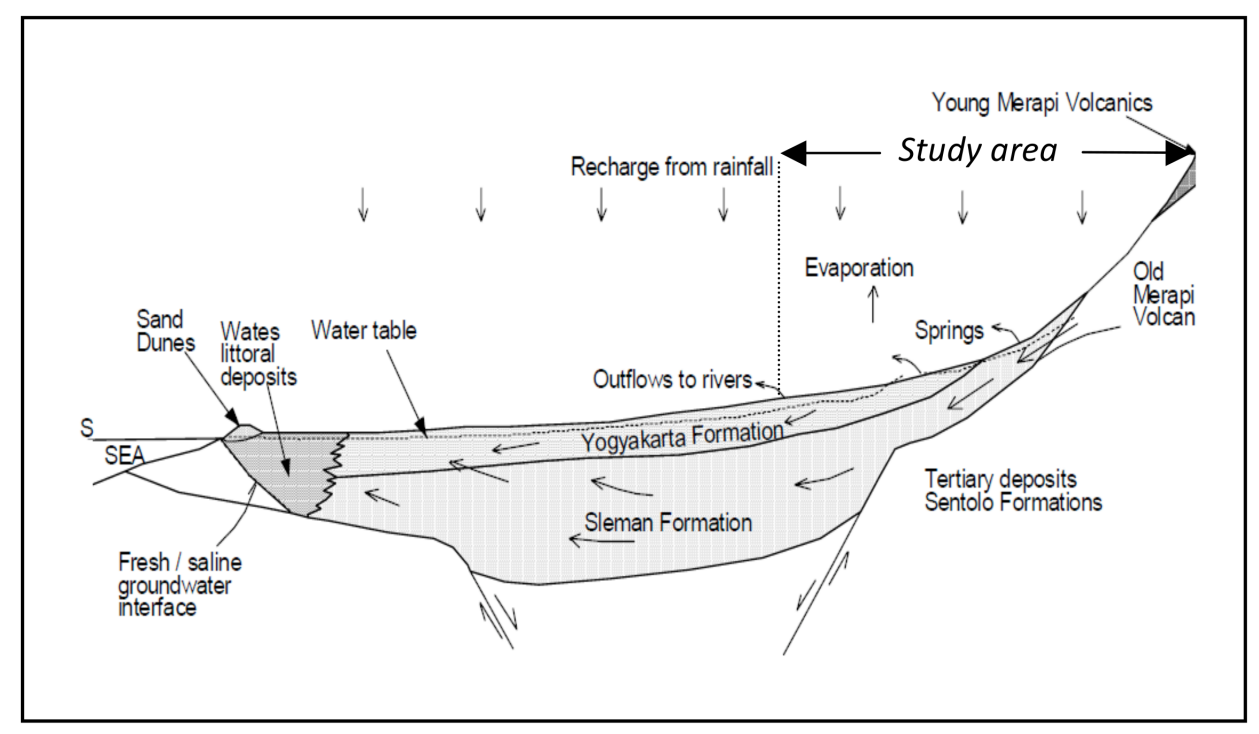

Figure 3: Conceptual model of Merapi Aquifer System from Merapi Volcano to the Indian Ocean (Modified from MacDonald and Partners, 1984).

\section{Theoretical Background}

The major ionic species in groundwater are $\mathrm{Na}^{+}, \mathrm{K}^{+}, \mathrm{Ca}^{2+}, \mathrm{Mg}^{2+}, \mathrm{Cl}^{-}, \mathrm{CO}_{3}^{2-}, \mathrm{HCO}_{3}^{-}$, and $\mathrm{SO}_{4}^{2-}$. All of these ions called as major ions as a dissolved representation of the aquifer lithology, chemical process and also can be used to determine the hydraulic connectivity, especially ion which are conservative like $\mathrm{Cl}^{-}$(Mazor, 2004).

Kurlov formula is a very useful method for primary characterization of the chemical composition of water (Zaporozec, 1972). On this method, chemical composition is expressed by a quasifraction with major anions and cations in the numerator and denominator, respectively. In designating the water type, only those constituents are considered which amount to more than $25 \%$ of the total meq/1. The Kurlov formula can be used for basic characterization of water composition in table or on maps. It is useful for general classification and as a basis for graphical methods and further interpretation (Zaporozec, 1972).

Figure 4 is a fingerprint diagram of the groundwater chemical composition data. In this figure each spring water is represent by one line that provides a visual description of the relative abundance pattern of the dissolved ions (the shape of each line) and the relative

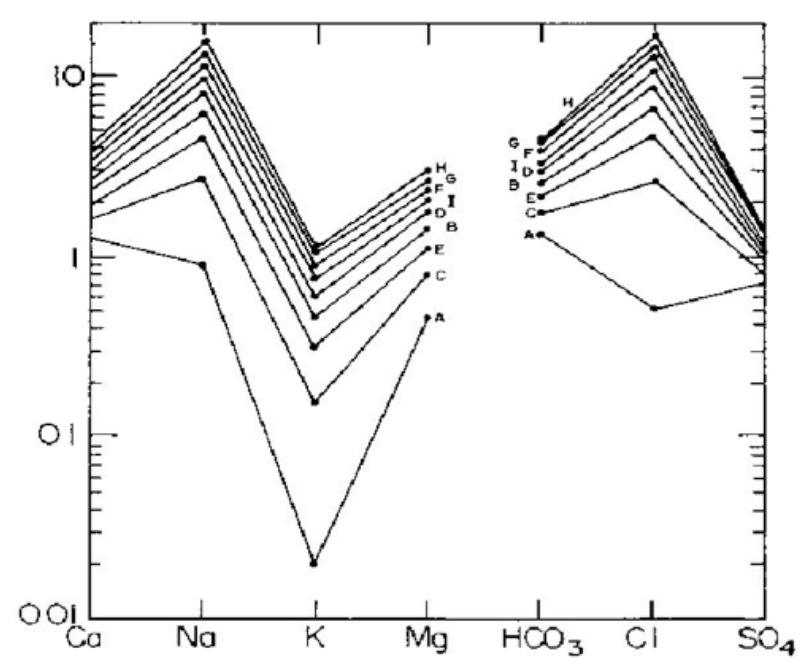

Figure 4: Fingerprint diagram (Mazor, 2004).

salinity (the position of the line at the upper or lower part of the diagram). Each line is the compositional imprint of a water sample and similar pattern means a relatively similar water type and sources (Mazor, 2004).

Pair of groundwater chemical parameters may be plotted in $x-y$ diagrams, or composition diagrams, in which concentrations are given in meq/l. The composition diagram provides a handy way to visually express large amounts of data, complementing the fingerprint diagram (Mazor, 2004). There are at least four major pat- 
terns seen in composition diagrams; a cluster (Figure 5), two clusters (Figure 6), triangular distribution (Figure 7 ) and random distribution (Figure 8).

\section{Methodology}

In order to answer the objectives, detailed field investigation was conducted for twelve springs in the study area from September, 2013 to May, 2014. The location of observed springs is shown in Figure 8 . Eleven springs were emerging from volcanoclastics deposits and only one spring which is Jatiningsih spring emerges from limestone aquifer. During the field investigation, physico-chemical properties of water such as water temperature, $\mathrm{pH}$, electric conductivity (EC) was measured including the springs discharge for every month. Moreover, samplings of lithology were also conducted for XRD analysis.

Secondary rainfall data in the study area is also collected to be used for evaluating the relation between spring discharge and changes of chemical composition of water. Springs water samplings were conducted twice during the field inverstigation period in the dry and wet season. The springs water was analysed for major ions such as $\mathrm{Na}^{+}, \mathrm{K}^{+}, \mathrm{Ca}^{2+}, \mathrm{Mg}^{2+}, \mathrm{HCO}_{3}^{-}$, $\mathrm{SO}_{4}^{2-}$ and $\mathrm{Cl}^{-}$(see Table 1 and 2), and evaluated based on the method of Kurlov formula for their water type classification. For understanding springs hydraulic connectivity in the study area, evaluation of chemical composition and fingerprint diagram were applied.

\section{Results and discussion}

Applying Kurlov formula for the dry and wet season data of spring water, the majority water type of spring in the southern slope of Merapi Volcano is classified as $\mathrm{Na}-\mathrm{Ca}-\mathrm{HCO}_{3}$ water, and only Jatiningsih spring falling on $\mathrm{Ca}-$ $\mathrm{Na}-\mathrm{Mg}-\mathrm{HCO}_{3}$ water type. These water type matches with the aquifer lithology (see Table 1 and 2). Result of XRD of the volcanoclastics deposits of Young Merapi deposits, Sleman formation and Yogyakarta formation (see Figure 9 show that these deposits are rich on plagioclase feldspar $\left(\mathrm{NaAlSi}_{3} \mathrm{O}_{8}\right.$ to $\left.\mathrm{CaAl}_{2} \mathrm{Si}_{2} \mathrm{O}_{8}\right)$, horn- blende $\left((\mathrm{Ca}, \mathrm{Na})_{2}(\mathrm{Mg}, \mathrm{Fe}, \mathrm{Al})_{5}(\mathrm{Al}, \mathrm{Si})_{8} \mathrm{O}_{22}(\mathrm{OH})_{2}\right)$ and pyrite $\left(\mathrm{FeS}_{2}\right)$. Due to high content of plagioclase and hornblende, groundwater on the volcaniclastic deposits of Merapi rich on $\mathrm{Na}^{+}$ and $\mathrm{Ca}^{2+} \mathrm{mg} / \mathrm{L}$. For Jatiningsih spring water, it is normal if calcium ion become the major cation than sodium because this spring emerges from limestone which commonly will rich on calcite $\left(\mathrm{CaCO}_{3}\right)$ to dolomite $\left(\mathrm{CaMg}\left(\mathrm{CO}_{3}\right)_{2}\right)$.

Plotting the chemical data on fingerprint diagram shows the spring water in the study area can be grouped into several groups. Figure 10 shows clearly the three group of spring water in the study area, in which three distinctive line pattern are recognized, which are orange and blue line representing water from spring Umbul Wadon, Bendosari 1, Bendosari 2, Dusan Gadung, Pusong, Beji, Duku, Tambakboyo 1, Tambakboyo 2, and Tambakboyo 3, dark blue line shows line pattern of water from spring "Pajangan", and red line is water from spring "Jatiningsih". Group 1 consists of ten springs which have similar chemical composition of $\mathrm{Na}-\mathrm{Ca}-\mathrm{HCO}_{3}$ and with electrical conductivity ranges between 150 to $200 \mu \mathrm{S} / \mathrm{cm}$. Group 2 consists only one spring "Pajangan" which contain similar chemical composition to Group 1 but has significantly higher ions concentration (EC value about $400 \mu \mathrm{S} / \mathrm{cm}$ ) and Group 3 consists also only one spring "Jatiningsih" which has significantly different dominant ionic composition with Group 1 and Group 2. Moreover, composition diagram of the chemical data also shows three distinct compositional water groups emerge (see Figure 11). Based on Figure 11. it can be concluded that: 1) there are three clusters of water which may representing difference aquifer system or source of water; 2) Pajangan spring water is fed by a water that has relatively higher $\mathrm{Cl}$ concentrations than the other springs; 3) Jatiningsih spring is fed by a water has relatively higher Ca concentration than the other springs; 4 ) there is possibility of intermixing water process on group 1 between water in aquifer and rainwater.

According to the result of fingerprint and compositional diagram evaluation, it is recognized that there are at least three aquifer system feeding those three groups of springs; shal- 

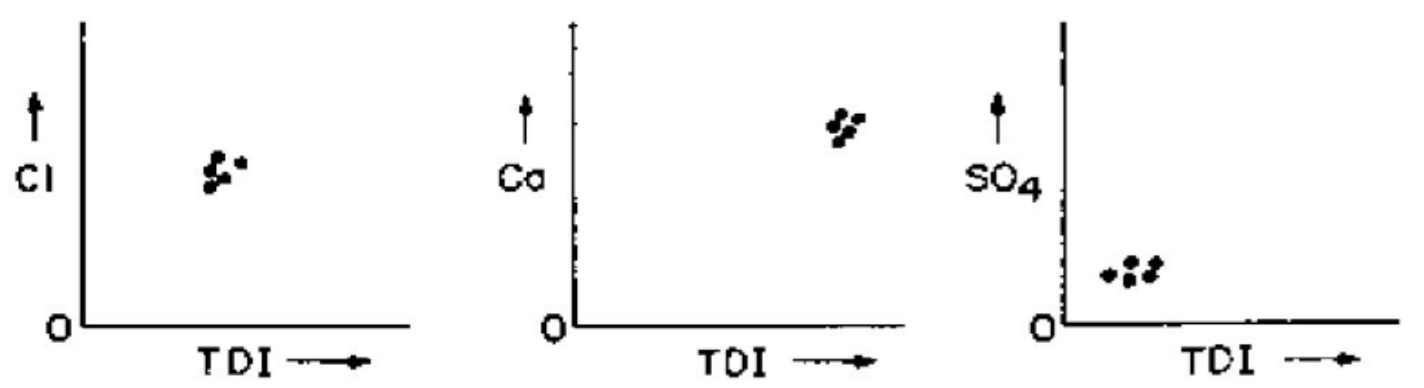

Figure 5: A cluster pattern in a set of composition diagrams of five adjacent springs. The pattern indicates one type of water is involved. The more parameters that are checked, the higher is the confidence of the conclusion (Mazor, 2004).
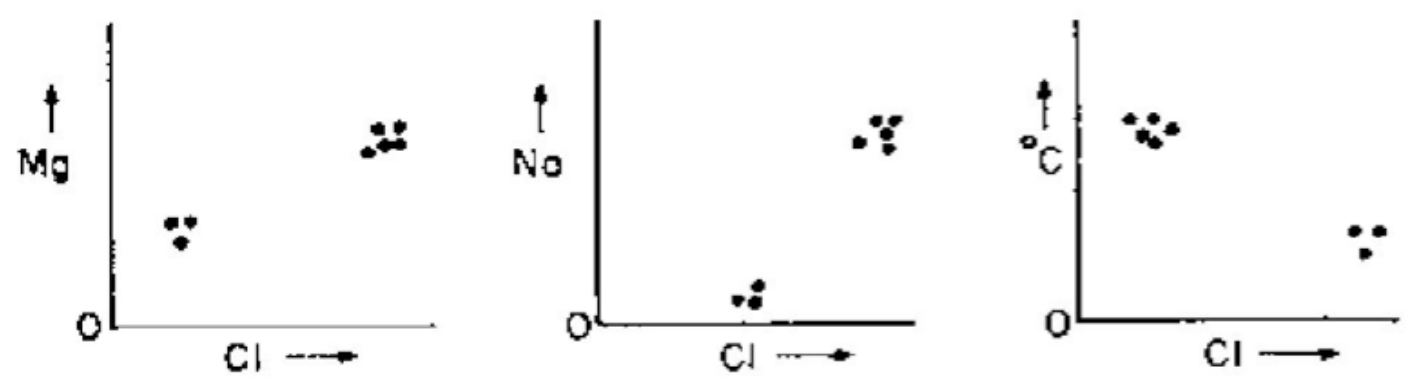

Figure 6: Two clusters in a set of eight adjacent springs. The pattern indicates two distinct types of water occur in the studied region (with no intermixing): a water type of low $\mathrm{Cl}, \mathrm{Mg}$, and $\mathrm{Na}$ and an elevated temperature, and a water type of high $\mathrm{Cl}, \mathrm{Mg}$, and $\mathrm{Na}$ and a low temperature (Mazor, 2004).
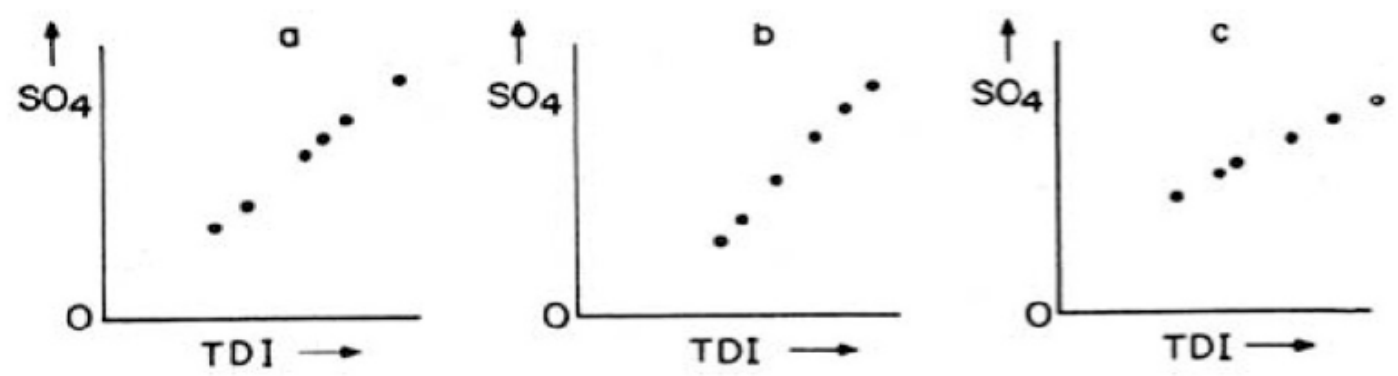

Figure 7: These are mixing lines, of which three variations are shown: (a) the line extrapolates to the zero points, indicating mixing of a saline water with a water that has neglegible $\mathrm{SO}_{4}$ concentrations (dilution); (b) the line extrapolates to a point in the TDI axis, indicating the fresher end member contains significant concentrations of ions other than $\mathrm{SO}_{4}$; and (c) the line extrapolates to the $\mathrm{SO}_{4}$ axis, indicating both intermixing waters contain significant concentrations of $\mathrm{SO}_{4}$ (Mazor, 2004). 


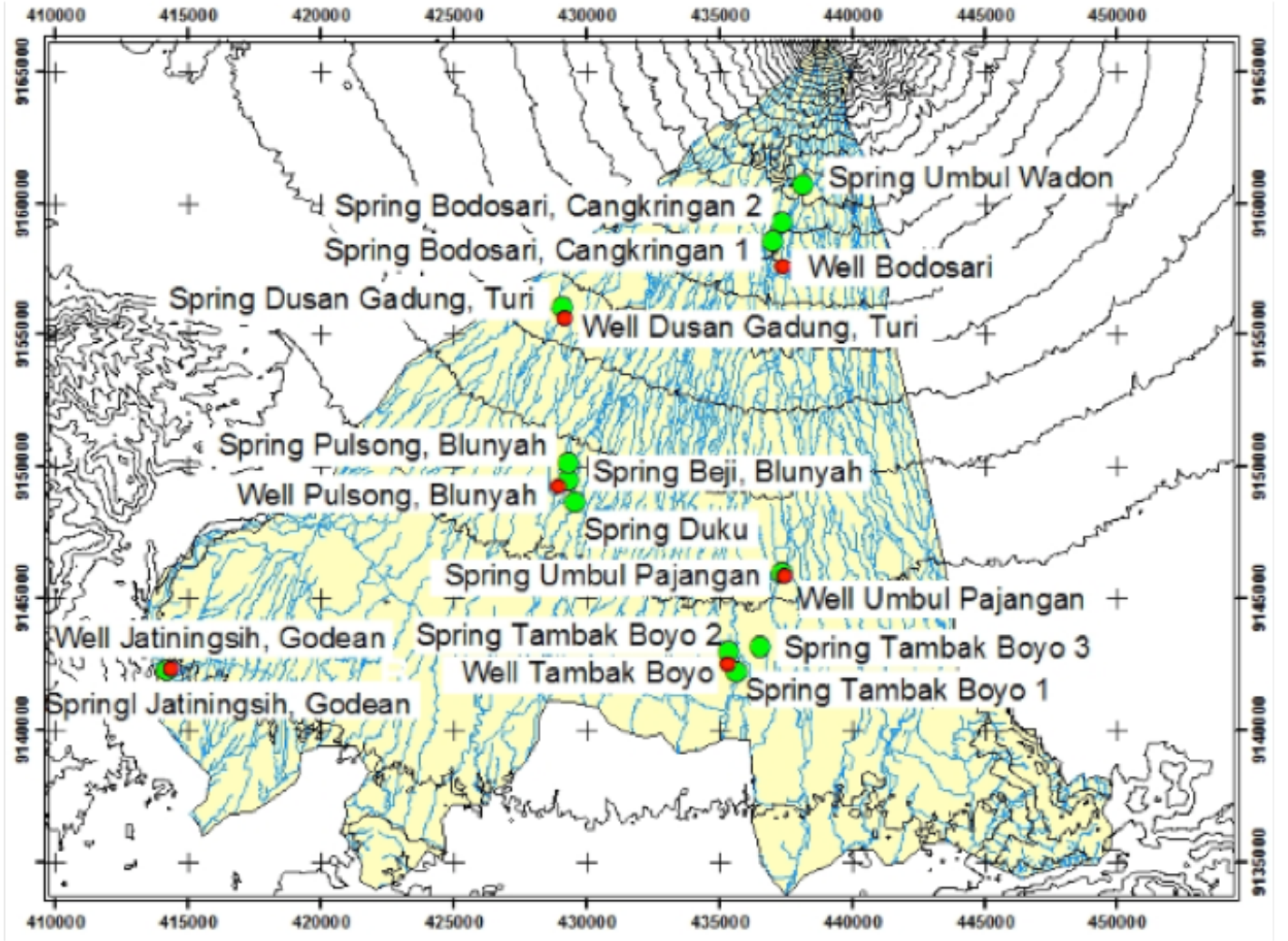

Figure 8: Location of the observed springs in the study area.

Table 1: Chemical composition of observed spring water in the study area collected at September 2013.

\begin{tabular}{|c|c|c|c|c|c|c|c|c|c|c|}
\hline \multirow{2}{*}{ Spring } & \multirow{2}{*}{$\begin{array}{l}\text { Elev. } \\
\text { (masl) }\end{array}$} & \multirow{2}{*}{$\begin{array}{c}E C \\
\mu S / c m\end{array}$} & \multicolumn{4}{|c|}{ Cation $(m g / l)$} & \multicolumn{3}{|c|}{ Anion (mg/l) } & \multirow{2}{*}{ Lithology } \\
\hline & & & $\mathrm{Ca}^{2+}$ & $\mathrm{Na}^{+}$ & $\mathrm{K}^{+}$ & $\mathrm{Mg}^{2+}$ & $\mathrm{HCO}_{3}^{-}$ & $\mathrm{Cl}^{-}$ & $\mathrm{SO}_{4}^{2-}$ & \\
\hline Umbul Wadon & 888 & 150 & 20.30 & 32.00 & 5.00 & 8.94 & 88.50 & 7.00 & 26.00 & $\begin{array}{l}\text { Young Merapi - } \\
\text { sand, gravel }\end{array}$ \\
\hline Bendosari 2 & 788 & 180 & 16.90 & 29.00 & 5.00 & 5.65 & 79.30 & 6.00 & 25.00 & $\begin{array}{l}\text { Sleman - gravelly } \\
\text { sand }\end{array}$ \\
\hline Bendosari 1 & 713 & 140 & 21.21 & 41.00 & 10.00 & 9.66 & 103.70 & 6.00 & 26.00 & $\begin{array}{l}\text { Sleman - gravelly } \\
\text { sand }\end{array}$ \\
\hline Dusan Gadung & 450 & 180 & 22.69 & 42.00 & 8.00 & 11.36 & 88.50 & 16.00 & 35.00 & Yogyakarta - sand \\
\hline Pusong & 263 & 190 & 24.68 & 37.00 & 8.00 & 8.70 & 115.90 & 7.00 & 23.00 & Yogyakarta - sand \\
\hline Beji & 250 & 200 & 26.27 & 41.00 & 6.00 & 10.40 & 115.90 & 7.00 & 28.00 & Yogyakarta - sand \\
\hline Duku & 238 & 180 & 19.90 & 43.00 & 7.00 & 8.70 & 109.80 & 7.00 & 21.00 & Yogyakarta - sand \\
\hline Pajangan & 225 & 410 & 19.10 & 137.00 & 9.00 & 16.92 & 231.80 & 37.00 & 51.00 & $\begin{array}{l}\text { Yogyakarta - } \\
\text { gravelly sand }\end{array}$ \\
\hline Tambak boyo 3 & 166 & 190 & 23.28 & 45.00 & 8.00 & 7.74 & 109.80 & 7.00 & 22.00 & Yogyakarta - sand \\
\hline Tambak boyo 2 & 150 & 200 & 26.67 & 47.00 & 8.00 & 9.91 & 122.00 & 8.00 & 26.00 & Yogyakarta - sand \\
\hline Tambak boyo 1 & 138 & 190 & 21.49 & 46.00 & 8.00 & 9.19 & 122.00 & 6.00 & 27.00 & Yogyakarta - sand \\
\hline Jatiningsih & 75 & 230 & 31.52 & 34.00 & 5.00 & 13.01 & 158.60 & 14.00 & 15.00 & Sentolo - limestone \\
\hline
\end{tabular}


Table 2: Chemical composition of observed spring water in the study area collected at May 2014

\begin{tabular}{|c|c|c|c|c|c|c|c|c|c|c|}
\hline \multirow{2}{*}{ Spring } & \multirow{2}{*}{$\begin{array}{l}\text { Elev. } \\
\text { (masl) }\end{array}$} & \multirow{2}{*}{$\begin{array}{c}E C \\
\mu \mathrm{S} / \mathrm{cm}\end{array}$} & \multicolumn{4}{|c|}{ Cation $(m g / l)$} & \multicolumn{3}{|c|}{ Anion $(m g / l)$} & \multirow{2}{*}{ Lithology } \\
\hline & & & $\mathrm{Ca}^{2+}$ & $\mathrm{Na}^{+}$ & $\mathrm{K}^{+}$ & $\mathrm{Mg}^{2+}$ & $\mathrm{HCO}_{3}^{-}$ & $\mathrm{Cl}^{-}$ & $\mathrm{SO}_{4}^{2-}$ & \\
\hline Umbul Wadon & 888 & 170 & 19.19 & 33.00 & 4.00 & 8.95 & 90.60 & 6.00 & 23.00 & $\begin{array}{l}\text { Young Merapi - } \\
\text { sand, gravel }\end{array}$ \\
\hline Bendosari 2 & 788 & 180 & 16.16 & 30.00 & 4.00 & 7.61 & 78.50 & 6.50 & 17.00 & $\begin{array}{l}\text { Sleman - gravelly } \\
\text { sand }\end{array}$ \\
\hline Bendosari 1 & 713 & 140 & 19.80 & 40.00 & 8.00 & 12.03 & 108.70 & 7.00 & 25.00 & $\begin{array}{l}\text { Sleman - gravelly } \\
\text { sand }\end{array}$ \\
\hline Dusan Gadung & 450 & 200 & 18.99 & 41.00 & 8.00 & 12.03 & 120.30 & 15.00 & 34.00 & Yogyakarta - sand \\
\hline Pusong & 263 & 210 & 20.60 & 38.00 & 6.00 & 12.27 & 120.80 & 7.00 & 19.00 & Yogyakarta - sand \\
\hline Beji & 250 & 160 & 24.04 & 47.00 & 7.00 & 10.80 & 120.70 & 9.00 & 25.00 & Yogyakarta - sand \\
\hline Duku & 238 & 190 & 19.80 & 50.00 & 10.00 & 9.57 & 106.60 & 8.50 & 28.00 & Yogyakarta - sand \\
\hline Pajangan & 225 & 410 & 17.78 & 136.00 & 10.00 & 17.43 & 169.10 & 37.80 & 52.00 & $\begin{array}{l}\text { Yogyakarta - } \\
\text { gravelly sand }\end{array}$ \\
\hline Tambak boyo 3 & 166 & 180 & 20.20 & 60.00 & 9.00 & 9.82 & 131.70 & 8.50 & 24.00 & Yogyakarta - sand \\
\hline Tambak boyo 2 & 150 & 160 & 19.39 & 59.00 & 8.00 & 8.59 & 138.70 & 7.00 & 17.00 & Yogyakarta - sand \\
\hline Tambak boyo 1 & 138 & 220 & 18.99 & 46.00 & 9.00 & 9.57 & 120.80 & 8.50 & 19.00 & Yogyakarta - sand \\
\hline Jatiningsih & 75 & 240 & 30.20 & 35.00 & 6.00 & 12.03 & 157.30 & 15.00 & 14.00 & Sentolo - limestone \\
\hline
\end{tabular}
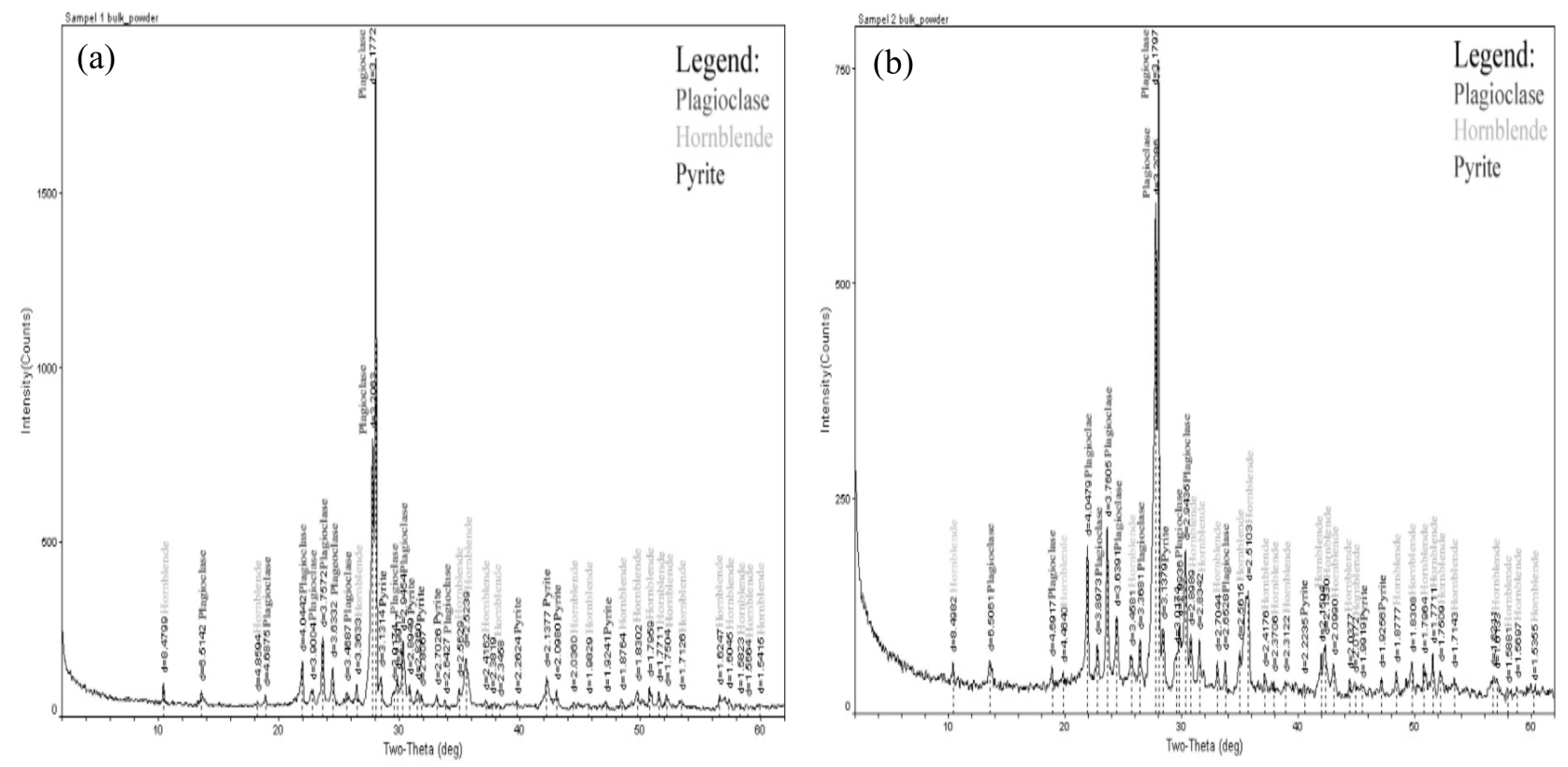

Figure 9: XRD analysis for the samples of (a) Sleman Formation lithology and (b) Yogyakarta Formation lithology. 


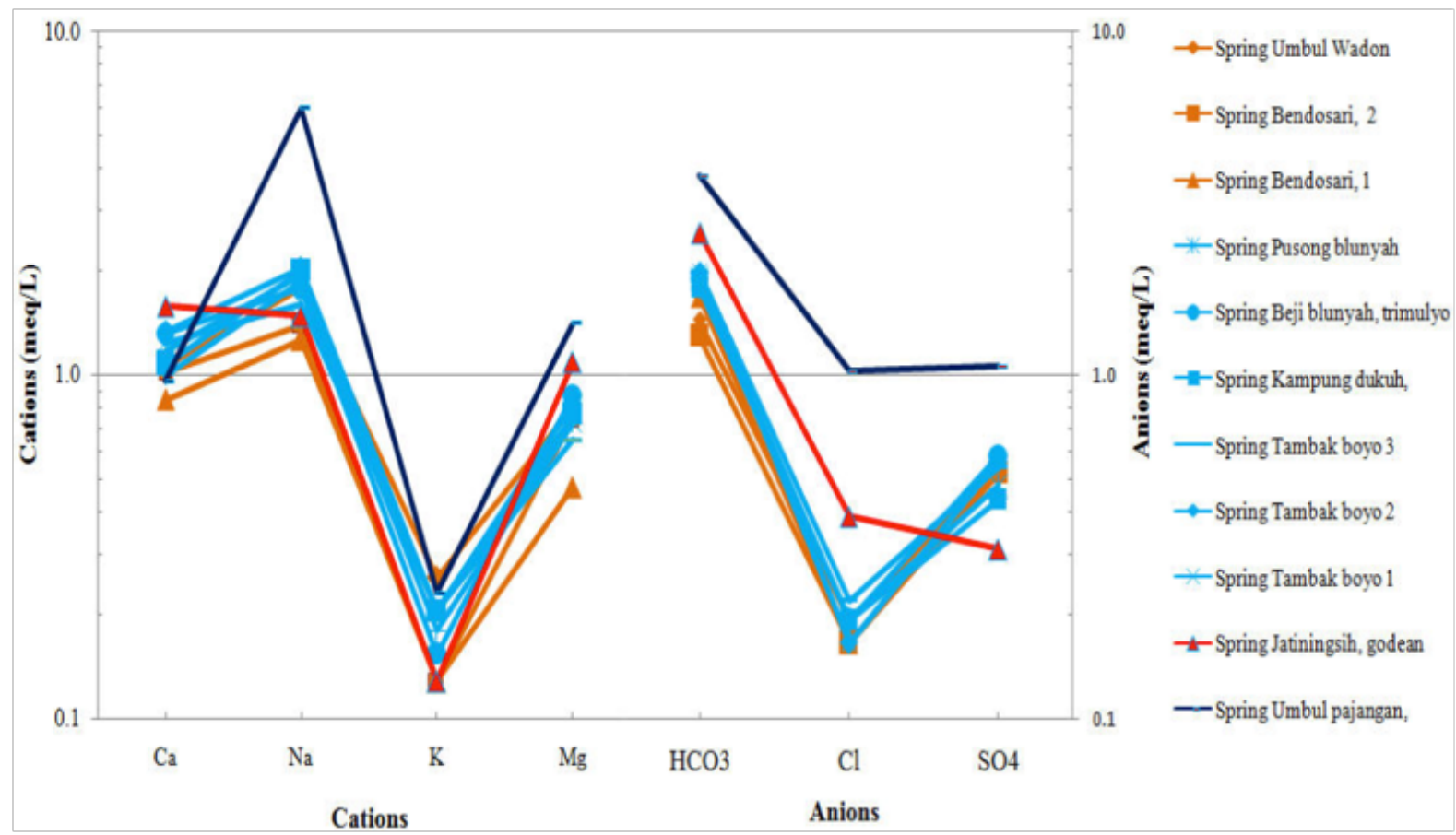

Figure 10: Fingerprint diagram of spring water chemical data in the study area.

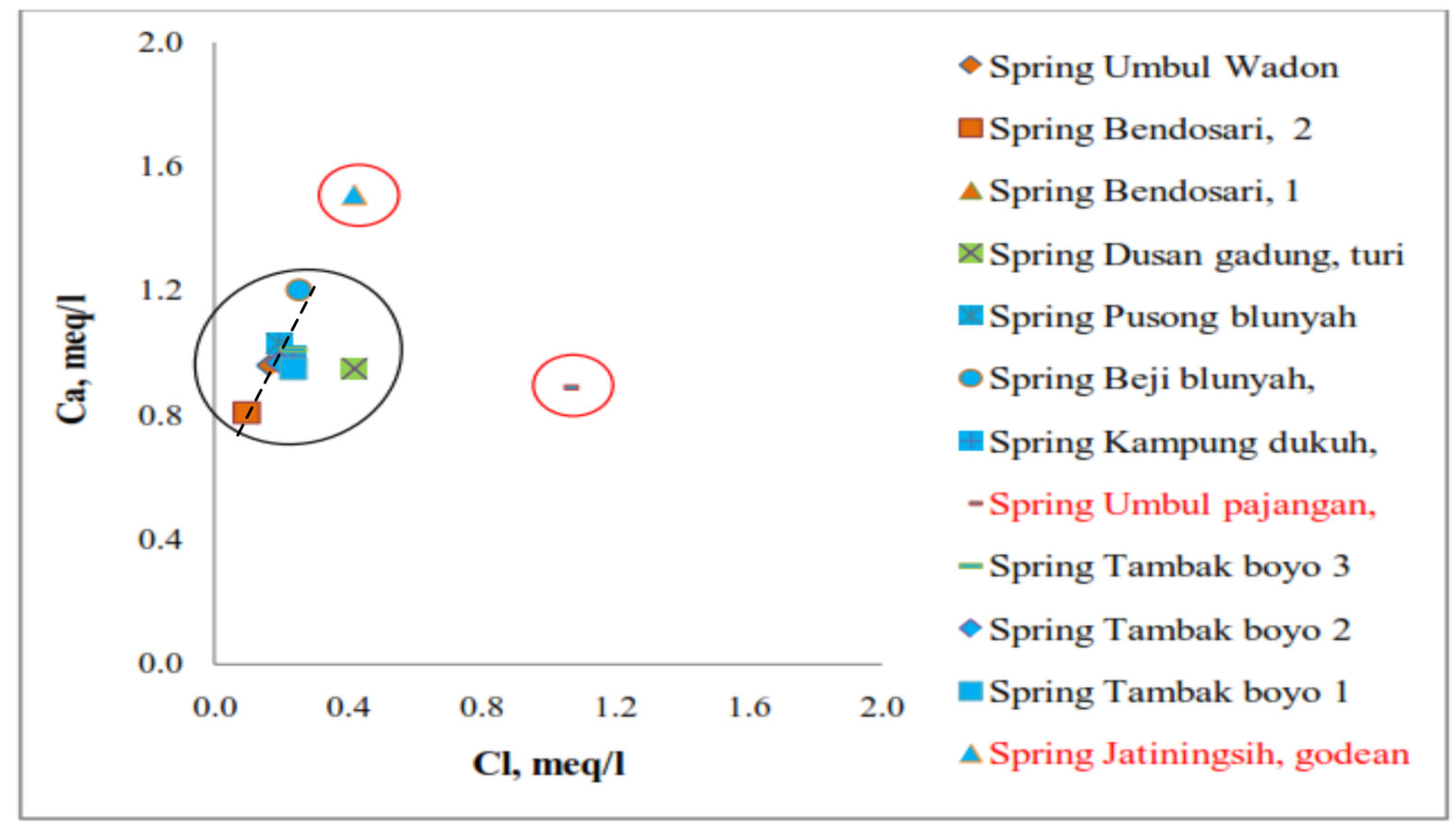

Figure 11: Compositional diagram of spring water chemical data in the study area. 
low aquifer system of MAS which affected by local rainwater recharge, deeper aquifer system of MAS and porous limestone aquifer of Sentolo formation. In order to prove this condition, comparison of rainfall data to the spring discharge is conducted for springs group 1 and group 2. Figure 12 shows clearly how the spring discharge of Umbul Wadon spring (group 1) following the trend of rainfall data, but this relation can not be seen for Pajangan spring (group 2 ) and this fact strongly support the argument that this water spring originate from deeper aquifer system of MAS. According to the result of this research a conceptual scheme of spring system in the southern slope of Merapi Volcano can be made and shown in Figure 13 .

\section{Conclusion}

Based on the fact found in the discussion above, there are some conclusions relate to this research can be taken, i.e.: 1) The majority water type of spring in the southern slope of Merapi Volcano is classified as $\mathrm{Na}-\mathrm{Ca}-\mathrm{HCO}_{3}$ water; 2) The water group in the study area can be classified into three distinct groups, in which group 1 consists of ten springs which have similar chemical composition of $\mathrm{Na}-\mathrm{Ca}-\mathrm{HCO}_{3}$ and with electrical conductivity ranges between 150 to $200 \mu \mathrm{S} / \mathrm{cm}$, group 2 consists only one spring "Pajangan" which contain similar chemical composition to group 1 but has significantly higher ions concentration (EC value about 400 $\mu \mathrm{S} / \mathrm{cm}$ ) and group 3 consists also only one spring "Jatiningsih" which has significantly different dominant ionic composition with group 1 and group 2; 3) Group 1 spring is hydraulically connected and relate to the shallow aquifer system of Merapi Aquifer System and affected by local rainwater, another side, water of spring "Umbul Pajangan" comes from deeper aquifer system of Merapi Aquifer System. However, it is presumably that water from Pajangan spring comes also from higher elevation in the slope of Merapi Volcano; 4) Finally, spring "Jatiningsih" is originate mainly from different aquifer system of porous limestone aquifer and does not hydraulically connection with group 1 and 2 .

\section{References}

Jai, M.P., Inayathulla, M., and Shahul H.A. (2013) Hydraulic Continuity between Groundwater Sources in the Proximity of Jakkur Lake of Bangalore - Evidence from Ion Chemistry, Journal of Engineering and Technology, Vol.2, Issue 3, p.128-135, Research and Reviews.

MacDonald and Partners (1984) Greater Yogyakarta Groundwater Resources Study Volume 3: Groundwater, 116 p, Directorate General of Water Resources Development Project (P2AT), Ministry of Public Works, Government of The Republic of Indonesia.

Mazor, E. (2004) Chemical and Isotopic Groundwater Hydrology, $3^{\text {rd }}$ edition, 453 p, Marcel Dekker Inc.

Praamsma, T., Novakowski, K., Kyser, K., and Hall, K. (2009), Using Stable Isotopes and Hydraulic Head Data to Investigate Groundwater Recharge and Discharge in Fractured Rock Aquifer, Journal of Hydrology, Vol.366, p.3545, Elsevier.

Putra, D.P.E. (2003) Integrated Water Resources Management in Merapi - Yogyakarta Basin, ASEAN University Network/South East Asia Engineering Education Development Network (AUNSEED-NET), Yogyakarta (Unpublished Report).

Wijatna, A.B., Sudarmadji, Sunarno, and Hendrayana, H. (2013) Tracing The Origin of Spring Water by Using Environmental Isotopes in the Southern Slope of Mount Merapi, Indonesia, Asean Engineering Journal Part C, Vol.2 No.2, p.118-130, ASEAN University Network/Southeast Asia Engineering Education Development Network.

Zaporozec, A. (1972) Graphical Interpretation of Water Quality Data, Department of Geology and Geophysics, University of Wisconsin, Madison, USA. 

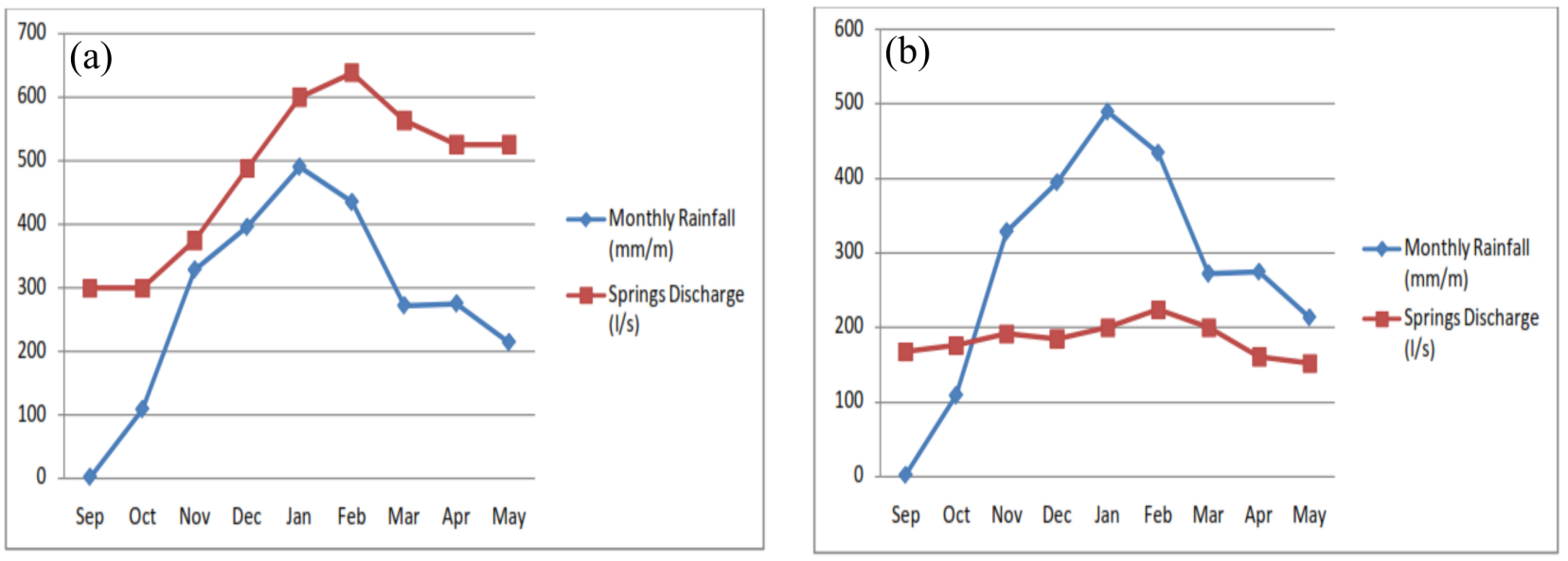

Figure 12: Comparison between monthly rainfall data in the study area with discharge of (a) Umbul Wadon spring discharge and (b) Pajangan spring discharge.

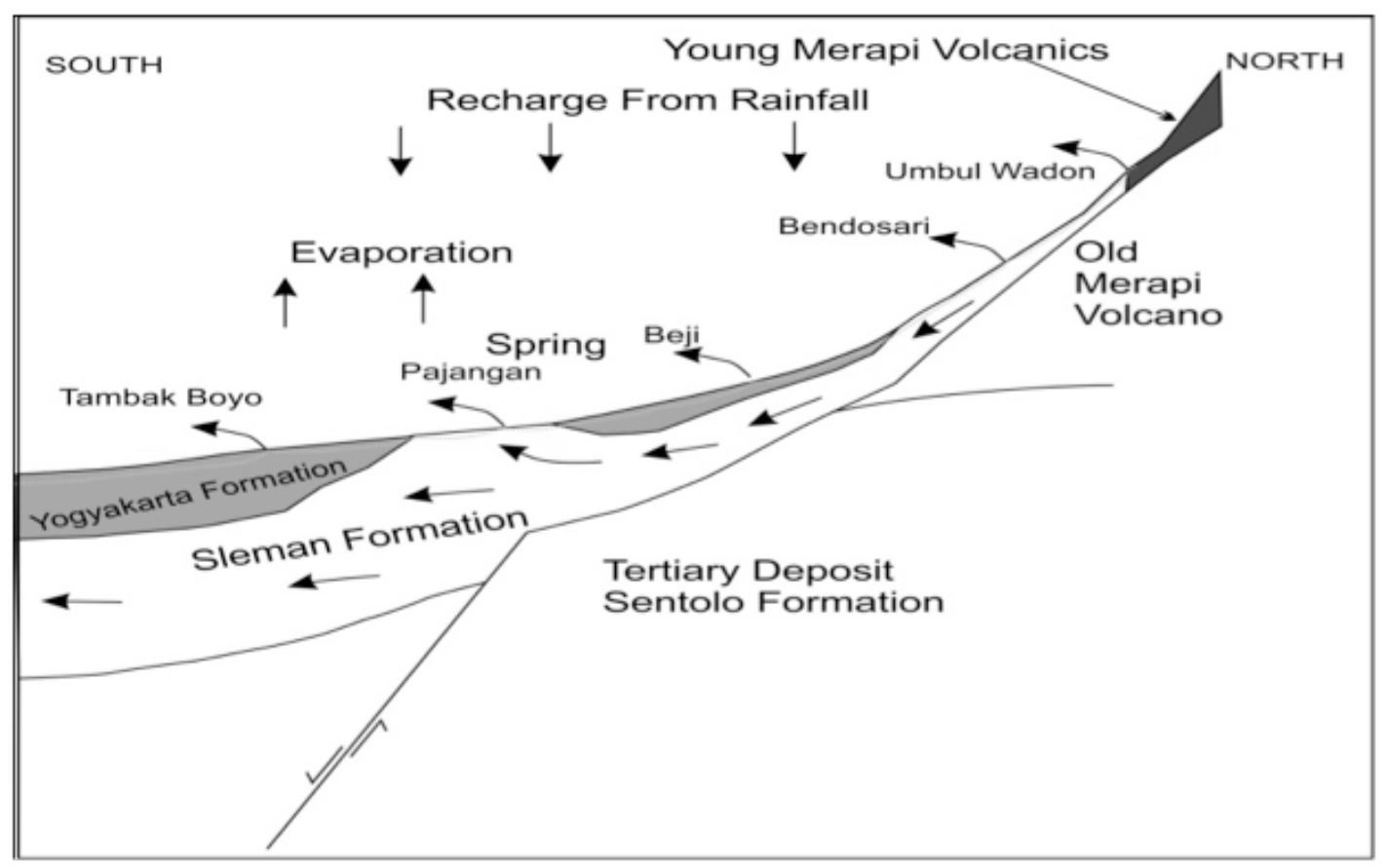

Figure 13: Conceptual model of spring occurrence in the southern slope of Merapi Volcano 